\title{
Parental Influence and Attitude of Students towards Technical Education and Vocational Training
}

\author{
Hina Ayub
}

\begin{abstract}
It is widely accepted that we live in a world where knowledge and technologies are renewing at an accelerating pace. Industrialization in Pakistan has become one of the crucial topics of discussion and concern in recent times and on the same time we are facing the challenges of underemployment and unemployment. Therefore, if we meet these challenges successfully, it will make significant improvements in terms of economic development, industrialization, and boost individual lifestyle and attract foreign investment. The purpose of this paper is to investigate the parental influence and student's attitude towards Technical Education and Vocational Training. In this study data was collected through questionnaire from all three zones of Technical Education \& Vocational Training Authority Punjab (Central, North, and South) and Two institutes from each zone and 50 students from each city $(25$ students from Vocational institutes and 25 Students from Technical Institute) and total 300 students were the sample of this study. Descriptive statistics and Multivariate Regression analysis is used to find the statistical impact of parental influence on Students Attitude towards Technical Education and Vocational Training.

The results of this study reveals that parental influence is statistical significant that impact on students' decision towards Technical Education \& Vocational Training. The findings of this study would be helpful for policy makers and head of Technical Education \& Vocational Training Authority Punjab institution for promotion of Technical Education and Vocational Training system in Pakistan and deal with ongoing challenges.
\end{abstract}

Index Terms - Technical education and vocational trainings, underemployment.

\section{INTRODUCTION}

Technical Education and Vocational Training is designed to prepare the individuals for specialize skills, abilities, trade, industries, agriculture and business for self-reliance and it is generally linked with manual and practical skills and commonly does not include academic abilities [1]. Vocational Training mostly includes education and training that emphasis more on manual work and prepares the individuals to perform for jobs that are related to working in a particular industry. Technical Education is parallel in nature to Vocational Training, but the attention is on technology and expansions made in computers and digital information. These skills help the individual's knowledge and information to enter and make progress in employment on productive basis.

Regardless of the increasing awareness for the need of skilled workforce in development, it looks like that there is no sufficient linkage between Technical Education \& Vocational

Manuscript received January 12, 2016; revised June 24, 2016.

Hina Ayub is with Leads Business School, Lahore Leads University, Pakistan (e-mail: blueribbon87@yahoo.com).
Training and work life [2].

The major benefit of TEVT system is that it support for alleviation of unemployment as it assist in increasing skills of youth for meeting the requirement of industry. The aims of Technical Education and Vocational Training system is to provide trained manpower in various applied fields, to provide Technical knowledge and Vocational skills. Trained and skilled workforce has significant role in 1) Economic development, 2) Industrialization, 3) Individual development and IV) to attract foreign direct investment [2].

Malaysia has accepted the significance of having more skilled workforce to support the technology-based work process in manufacturing, production and to attract foreign direct investment in moving towards work based economy. In order to support it the government has expanded more resources for the development of Technical and Vocational institutes. The ability and competency of the Technical Education and Vocational Training system is further supported to increase the quantity and quality of skilled workforce [2].

In Vocational institutes the emphasis is given on skilled and manual base work which is the need of related industry. The primary objective of the TEVT system is to enhance both technical and non-technical skills of an individual so that they can be employed on a suitable and industrial base [3].

Rate of enrolment and completion rate of Technical and Vocational courses in Technical and Vocational institutes is going to be low day by day which is ultimately decreasing well trained workforce in any country [3]. Most students and parents still choose the academic stream rather than the Technical Education \& Vocational Training while many efforts has been made by the Government for the promotion and to aware the community regarding the benefits of the existing Technical Education and vocational training system [3].

Students with low academic achievement cannot study at colleges but still they have the opportunity to study at Technical and Vocational Institutes. Technical and Vocational system provides the labor market with skilled and semi-skilled workforce in different trades [3]. Vocational Education Institutes offer basic academic knowledge but focus is on practical and manual vocational training to prepare them for employment in lower level technical positions [3]. Change in polices and development of Technical Education and Vocational Training is linked with human resource development and economic development worldwide. Thai government is working to increase the capacity of Technical Education and Vocational Training sector in order to meet the demand of skilled workforce. In 2007 Thailand Ministry of Education aimed to increase $20 \%$ enrolment in Technical and 
Vocational Institutes [4].

Technical and Vocational Education has been an important role for national development of every country because it plays an important role in economic development of any country [5].

Unemployment and underemployment are two thoughtful issues being confronted by many countries including Pakistan and these issues becoming hurdle in the way of economic development of any country. Rate of unemployment can be decreased by employability and economic growth of an individual; however poor people cannot be employed without any employable skill. Therefore this challenge can be meet by producing demand driven skill worker through Technical and Vocational Education [5].

Pakistan is considered in those countries whose unemployment rate is higher including male and females. In 2012 the unemployment rate in Pakistan is recorded $7.8 \%$ that is very high, while in 1987 it was 3.1\%. In year 1985 till 2014-2015 the average unemployment rate in Pakistan recorded is $5.4 \%$ (Statistical Beauru). Technical Education \& Vocational Training system can help when there are regional job opportunities but they do not match the outline and skills of workers, and the pattern of the jobs is different from workers skills [6]. Current educational system of Pakistan is not preparing the youth as per the need of the market demand [6].

The requirement for skilled workforce is increasing day by day but the lack of skilled work force is the serious issue in the various sectors of industrial production [6]. Parents should encourage their children for Technical Education and Vocational Training and they should reject this perception that this field is for low academic background students [7]. There are lots of field of education which are just raising unemployment, poverty and misery in Nigeria. Situation can be change if curriculum is to be redesigned as per the demand of the labour market [8].

In Pakistan educational system does not provide the skills and knowledge which is required by labour Market. Lack of skills in educated youth, high level of expectation from job are the causes which is creating unemployment in educated youth in Pakistan [9]. In Pakistan Hussain, (2005) investigated 5 reasons of unemployment in her research and one of the serious reasons is that there is miss match between job or skill demanded by emerging economy and supply of skilled manpower. She is further investigated that our economy is moving towards technical and Vocational sector and our colleges and universities are producing thousands of graduated in Art, Language and Humanities.

In Punjab the TEVT system is controlled jointly by different agencies such as Technical Education and Vocational Training Authority (TEVTA), Punjab Vocational and Training Council (PVTC), Punjab Skill development Foundation (PSDF) and others private institutes. Provision of well-trained and skilled workforce is the main objective of Technical Education and Vocational Training system.

\section{RESEARCH OBJeCtive}

To explore the impact of parental influence on Student's attitude towards Technical Education and Vocational Training.

\section{SIGNIFICANCE OF STUDY}

No research was taken regarding issues and problems of Technical Education \& Vocational Training in Pakistan so this study will be very great contribution for strengthen this system in Pakistan.

This study would be beneficial for Head Technical Education \& Vocational Training in Pakistan to understand the impact of parental influence on student's attitude towards Technical Education and Vocational Training. Negative attitude of students leads towards bad image of Technical Education and Vocational Training in society. This issue is affecting on enrolment of TEVT institutes and in results skilled workforce is decreasing in Pakistan.

\section{LITERATURE REVIEW}

\section{A. What Is Attitude?}

Attitudes are the views a person takes about objects, people group and issues. Overall attitude can be positive, negative, neutral and can be vary from situation to situation. Attitude is central concept in social science because it plays an important role in influencing much different behavior. Attitude is the broader term and an attitude represents general orientation of the individual. Interest on the other hand is more specific and directed towards a particular objects or activity. Attitude are acquired through experiences social interaction but once established they tend to be relatively enduring. People in their daily life interact with different people, the people views about certain thing change by interaction. [10].

\section{B. Formation of Attitude}

Attitude formation is the result of learning, experiencing different situations, different group of people etc. and it effects on the decision making, choices. Attitude that comes and impacted from different experiences can be measured and reformed [11].

\section{Attitude Change}

Modification in person views or individual perception about anything in the environment, objects or issues is called Attitude change. In America millions of dollars are spent on advertisements and it is estimated that average person attitude can be changed by persuasive. Even a very tiny fraction of these appeal are effective and attitude of individual are in constant change. The most important findings in the area of attitude change are that repeated reinforcement, exposure to unfamiliar situation results in positive attitude towards the situation [11]. Attitude can be change through socialization and influenced by different factors like family, culture, religion and socioeconomic factors and it impact on individual attitude toward work or particular behavior [12]

\section{Conditioning and Modeling Approach}

Review of basic principles of learning from studies of classical and operant conditioning explains about person's 
attitude formation and change by the repeated reinforcement to the stimulus. The main purpose of these theories is to understand the impact of conditioning on attitude formation. The attitude towards stimuli becomes more favorable / unfavorable if they are linked with pleasant / unpleasant constrains (classical conditioning) or associated with positive / negative outcomes (operant conditioning). Conditioning has important and powerful in attitude formation rather than attitude change [12].

\section{E. Persuasion Theory}

The theory of persuasion suggests that peoples' attitude can be changed in two ways. First they can be motivated to listen and think about the message thus leading towards attitude shift or they might be influenced by the characteristics of speaker. Early studies on persuasion focus that there are three factors which effect on persuasion these are the communicator, the message and the audience. Cognitive approach reveals that persuasion can be in two paths one is central and other is peripheral. In the central path of persuasion the attitude change depends upon the inherent argument presented where as in the peripheral persuasion the attitude change is depends upon the attractiveness of communicator and the presentation of the message [12].

The result of O. Kissim et al. (2011) research shows that parents have perception that girls who study Industrial and Technical Education do not get married. Some parent's belief that religious belief does not allow them to study their girls courses which boys study. Parents are also asked to suggest ways by which this issue could be resolved. Parents suggested that early counseling to girls about career would play an important role and female technical instructor as a role model in institutes would encourage students to choose this career. Parents also suggest that agencies, government industries and women associations should promote activities to educate public for different opportunities for girls that are available for females. Conclusion of this research is that parents, teachers and girls cannot fill the gap between Industrial and Technical education. Government and Non-government organizations should work together to support gender equity program [13].

The finding of Maria Mrs, (2009) research is that parents are aware from the employed value in vocational education but still they are status conscious of professions like Laws, Medicine, Accounting, over Technical Education and Vocational Training related jobs. This reveals deeper societal prejudice against Manual labor. This research gave suggestion for policy maker to establish guidance and counseling centers which will provide clear understanding of this program to the clients (Parents). These services should be provided both within and outside the school system to achieve the meaningful attitude in desired direction [14].

Alandas, (2002) investigated from their research that fathers had lower economical and educational level so this indicates that they support their children to enroll in technical education. Al-sa'd, (2007) Mustapha et al. (2010) [15], Lavendets et al. (2012) Maria Mrs (2009) [16], Ohiwerei and Nosu, (2009) [17], Igbinedion, (2011) [18], Alandas, (2002) [19] Investigated the impact of parental influence on student's attitude towards Technical Education and Vocational
Training. Parent's educational level, occupational and income have significant impact on student's choice towards Technical Education and Vocational Training [15]-[18].

Al-sa'd, 2007, Mustapha et al. 2011, Lavendets et al., 2012, Maria Mrs. 2009, Alandas, 2002 [19], Ohiwerei and Nosu, 2009, Igbinedion 2011 investigated that Parent's educational level, occupational and income have significant impact on students' choice towards Technical Education and Vocational Training.

\section{THEORETICAL FRAMEWORK}

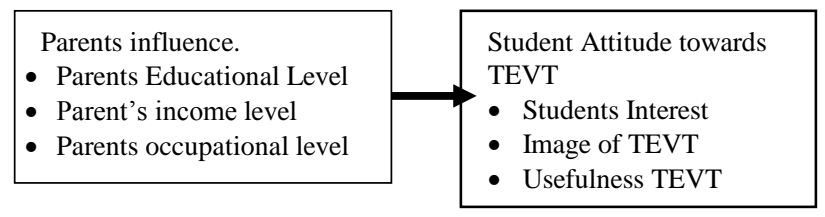

\section{HYPOTHESES}

H1: The Parental role is positively related with student's attitude towards Technical Education and Vocational Training.

\section{RESEARCH METHODOLOGY}

\section{A. Population and Sample}

The target population for this study is Technical and Vocational Institutes working under the umbrella of Technical Education and Vocational Training Authority (TEVTA) Punjab. The main demographic characteristic of this research are gender (male and female) and area of residence ( urban and rural) There are three zones in Punjab so one Technical and Vocational institute from urban area and one from rural area from each Zone were selected for data collection.

\section{B. Sampling Procedure}

\begin{tabular}{|c|c|c|c|}
\hline TABLE I: SAMPLING PROCEDURE \\
\hline Gender & $\begin{array}{c}\text { Students } \\
\text { of } \\
\text { Technical } \\
\text { Institutes }\end{array}$ & $\begin{array}{c}\text { Students of } \\
\text { Vocational } \\
\text { Institutes }\end{array}$ & Total \\
\hline \multicolumn{4}{|c|}{ Region } \\
\hline Central & 50 & 50 & 100 \\
\hline North & 50 & 50 & 100 \\
\hline South & 50 & 50 & 100 \\
\hline Total & 150 & 150 & 300 \\
\hline
\end{tabular}

\section{Instrument Development}

The measurement of impact of Parental influence (independent variables) is based on instruments that have been used in past studies and have been proven to have high reliability and validity. Al-sad 2007, Pimpa 2007, Awang 2011, Alandas (2002), Ozioma (2011). 
Descriptive statistics was used to explain the respondent's response and to explain independent variable researcher use frequency and percentage statistics. Researcher used more than one dependent and independent variables in this study that why multi variable regression analysis was used to find out the relationship among variables. $\mathrm{T}$ test was used to determine the statistical significant between the dependent and independent variable.

TABLEII: PARENTAL INFLUENCE ON STUDENTS ATTITUDE TOWARDS TEVT

\begin{tabular}{|c|c|c|}
\hline & Parental Influence & \%response \\
\hline Strongly Disagree & 3 & 1.09 \\
\hline Disagree & 16 & 5.84 \\
\hline Neutral & 29 & 10.58 \\
\hline Agree & 171 & 62.41 \\
\hline Strongly Agree & 55 & 20.07 \\
\hline
\end{tabular}

Results of above Table II shows that $62 \%$ respondents are agree that there is parental influence on their attitude and $20 \%$ respondents are strongly agree that there is parental influence on their attitude. About $10 \%$ of the respondents have no views about the role of parents on their attitude towards Technical Education and Vocational Training. Whereas 5\% Respondents are disagree and about $1 \%$ students are strongly disagreeing that their parents have influence on their attitude towards Technical Education and Vocational Training.

\section{REGRESSION MODELS}

Model-1 Impact of parental influence on Student Attitude

$$
S A=\alpha+\beta_{1} P E I+C_{i}
$$

Model-2 Impact of parental influence on developing Student Interest

$$
S A_{1}=\alpha+\beta_{1} P E I+C_{i}
$$

Model-3 Impact of parental influence on developing image of TEVT

$$
S A_{2}=\alpha+\beta_{1} P E I+C_{i}
$$

Model-4 Impact of parental influence on developing

\begin{tabular}{|c|c|c|c|c|c|c|c|c|}
\hline \multicolumn{3}{|c|}{ Father's Educational Level } & \multicolumn{3}{|c|}{ Father's Occupation } & \multicolumn{3}{|c|}{ Father's Monthly income } \\
\hline Educational Level & Frequency & Percentage & Occupation & Frequency & Percentage & Income Level & Frequency & Percentage \\
\hline Illiterate & 71 & 25.91 & Unemployed & 14 & 5.11 & Rs0 -Rs10000 & 114 & 41.61 \\
\hline Primary & 58 & 21.17 & Farmer & 62 & 22.63 & $\begin{array}{c}\text { Rs10000--Rs2000 } \\
0\end{array}$ & 91 & 33.21 \\
\hline Matric & 114 & 41.61 & Teacher & 7 & 2.55 & $\begin{array}{c}\text { Rs20000--Rs3000 } \\
0\end{array}$ & 40 & 14.60 \\
\hline FA/Diploma & 10 & 3.65 & Banker & 5 & 1.82 & Rs30000-Rs40000 & 25 & 9.12 \\
\hline Bachelor Degree & 12 & 4.38 & Businessman & 47 & 17.15 & & & \\
\hline M.A & 5 & 1.82 & Labour Job & 130 & 47.45 & & & \\
\hline PHD & 0 & 0.00 & & & & & & \\
\hline
\end{tabular}
usefulness of TEVT.

$$
S A_{3}=\alpha+\beta_{1} P E I+C
$$

TABLE IV: DEPENDENT \& INDEPENDENT VARIABLE

\begin{tabular}{|c|c|}
\hline Dependent Variable & Independent Variable \\
\cline { 1 - 1 } $\mathrm{SA}=$ Student Attitude Towards TVE & \multirow{2}{*}{ PEI = Parental Influence } \\
\cline { 1 - 1 } $\mathrm{SA}_{1}=$ Students Interest & \\
\cline { 1 - 2 } $\mathrm{SA}_{2}=$ Image of TVE & \\
\cline { 1 - 2 } $\mathrm{SA}_{3}=$ Usefulness and importance of TVE & \\
\hline
\end{tabular}

Result of above Table III shows that majority of the parents educational level is Matric or lower. Majority of the respondent fathers' occupation is Labour and income level is between Rs0-Rs10000. It shows that parent with low academic, income level and occupation level only influence their children towards Technical education and Vocational Training.

\section{RESEARCH FINDINGS AND DISCUSSION}

Most of the previous researches concluded that parents have significant influence on students' attitude towards Technical and Vocational Education. Lavendets (2012), Mari
Mrs (2009) Al-sad, (2007), Ohiwerei and Nosu (2009) investigated the impact of parental influence on students' attitude towards Technical and Vocational Education. they find out that Parents' educational level, occupational and income have significant impact on students' choice towards Technical and Vocational Educational. The findings of this research reveal that parents have significant impact on students' attitude towards Technical and Vocational Education. The majority of respondent's parents have lower economic, educational and occupational background in the society. According to findings of this research it shows that parents with lower socioeconomic status in the society encourage their children to join Technical and Vocational Education.

The findings of this research reveal that socioeconomic status of family has significant impact on student's attitude towards Technical and Vocational Education. Awang et al. (2011), Ozioma (2011), Pimpa (2007) investigated that students have perception that Technical and Vocational education is for students from Poor socioeconomic 
background. Lavendets et al. (2012) find out that parents place of living impact on their children for selection VET as career. The findings of this research reveal that parents with poor socioeconomic status influence their children to join Technical Education and Vocational Training,

\section{RECOMMENDATIONS}

Results of this study along with the literature support, showing that parents influence is an important factor in order to develop student interest toward Technical Education and Vocational Training. This study shows that parents with low academic, economic and occupational background only influence their children for Technical Education and Vocational Training. There are suggestions for Policy Makers and Head of TEVT institutions to promote non-conventional education (Technical and Vocational) schooling in Pakistan by arranging "Parents Teachers Meeting" with Parents at secondary schools.

Technical/Vocational Boards Official and Head of TEVTA Institutions can play vital role to promote importance of TEVT in Pakistan by arranging guidance and counselling sessions with parents during "Parents Teachers Meeting" at secondary schools. Representative of TEVT can play an important role by guiding parents regarding importance to Technical education and Vocational Training during that meeting.

\section{REFERENCES}

[1] O. C. Azubuike, "Influential factors affecting the attitude of students towards vocational technical subjects in secondary schools in Southeastern Nigeria," Journal of Educational and Social Research, vol. 1, no. 2, pp. 49-56, 2011.

[2] H. Awang et al., "Image and students' loyalty towards technical education and vocational training," Journal of Technical Education and Training (JTET), vol. 3, no. 1, pp. 13-28, June 2011.

[3] A. Al-sa'd., "Evaluation of student' attitudes toward vocational education," PhD dissertation, Malmö Studies in Educational Sciences, no. $32,2007$.

[4] N. Pimpa, "Reference groups and choices of vocational education: Case of Thailand," AARE 2007 International Education Research Conference, p. 15, 2007.

[5] A. I. Oseni et al., "Technical and vocational education: Key to poverty alleviation in the third world with particular reference to Nigeria," Journal of Education and Practice, vol. 2, no. 6, pp. 64-70, 2011

[6] M. Kassotakis, "Technical and vocational education in greece and the attitudes of greek youngsters toward it," Journal of the Hellenic Diaspora, pp. 81-93, 1978.

[7] M. A. Yusuff and J. Soyemi, "Achieving sustainable economic development in Nigeria through technical and vocational education and training: The missing link," International Journal of Academic Research in Business and Social Sciences, vol. 2, no. 2, pp. 71-77, 2012.
[8] D. P. Ojimba, "Vocational and technical education in Nigeria: issues, problems and prospects' dimensions (IPP)," Journal of Educational and Social Research, vol. 2, no. 9, pp. 23-30, 2012.

[9] I. Husain, "Education, employment and economic development in Pakistan," Education Reform in Pakistan: Building for the Future, pp. 33-45, 2005

[10] S. Alandas, "Attitude of freshman in Saudi technical colleges towards technical-vocational education," PhD Dissertation, the Ohio State University, 2002.

[11] J. Cacioppo, R. Petty, and S. Crities, "Attitude change," Encyclopedias of Human Behavior, vol. 1, pp. 261-270, 1994.

[12] L. R. Glasman and D. Albarracín, "Forming attitudes that predict future behavior: A meta-analysis of the attitude-behavior relation," Psychological Bulletin, vol. 132, no. 5, p. 778, 2006.

[13] O. A. Kissim, O. A. Omolade, and O. A. Rachael, "Parental role in gender stereotyping in vocational education in 21st century, Nigeria," Journal of Basic and Applied Scientific Research, vol. 1, no. 7, pp. 627-633, ISSN 2090-424X, 2011.

[14] O. Maria, "Parental attitudes towards vocational education: implications for counseling," Edo Journal of Counselling, vol. 2, no. 1, pp. 81-89, 2009.

[15] R. Mustapha, N. Long, and F. Mohd, "Career decision process among women in technical fields," in Proc. the $1^{\text {st }}$ UPI International Conference on Technical and Vocational Education and Training Bandung, Indonesia, November 10-11, 2010, pp. 557-569, 2010.

[16] J. Lavendets, V. Sitikovs, and M. Uhanova, "Influence of socio-demographic characteristics to attractiveness and success of initial vocational education and training in latvia," Social and Behavioral Sciences, vol. 55, pp. 756-765, 2012.

[17] F. Ohiwerei and B. Nwosu, "Vocational choices among secondary school students: Issues and strategies in Nigeria," Asian Journal of Business Management, vol. 1, no. 1, pp. 1-5, May 2009.

[18] V. Igbinedion, "Perception of factors that influence students' vocational choice of secretarial studies in tertiary institutions in Edo state of Nigeria," European Journal of Educational Studies, vol. 3, no. 2, pp. 325-337, 2011.

[19] S. Alandas, "Attitude of freshman in Saudi technical colleges towards technical-vocational education," PhD Dissertation, the Ohio State University, 2002.

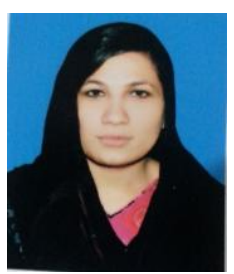

Hina Ayub was born at Lahore, Pakistan on May 11, 1983. Ms Hina Ayub did her degree masters of philosophy in management sciences from Leads Business School Lahore Pakistan in December 2015 and currently she is seeking admission $\mathrm{PhD}$ in management sciences.

She is working as principal in Technical Education and Vocational Training Authority Punjab Pakistan since 2011. She has been working in various Vocational Institutes of Technical Education and Vocational Training Authority Punjab Pakistan. Currently she has established Govt. Vocational Training Institute Samanabad Lahore Pakistan and working as principal in the same institute. She had published few research papers in international conferences. Her area of interest is Management of Technical and Vocational Institute Skill Development to overcome unemployment.

Ms. Hina has also in the expert/assessor pool of National Vocational and Technical Training Commission (NAVTTC) Pakistan for Accreditation of TEVT Institutes in Pakistan. She has won a best research Paper award in International Conference on Business Economics and Management (ICBEM'2015) Dec. 15-16 2015 Pattaya (Thailand) entitle paper Factors affecting Students' attitude towards Technical Education and Vocational Training. 